\title{
VERIFICATION OF APPLICABILITY OF FOREST GROWTH MODEL AGM IN ELABORATION OF FORESTRY PROJECTIONS FOR NATIONAL FOREST REFERENCE LEVEL
}

\begin{abstract}
Andis LAZDIN̦Š Latvia State Forest Research Institute “Silava”, Rigas street 111, LV-2169, Salaspils, Latvia; andis.lazdins@silava.lv (corresponding author)

Guntars ŠN̦EPSTS Latvia State Forest Research Institute "Silava”, Rigas street 111, LV-2169, Salaspils, Latvia; guntars.snepsts@silava.lv

Guna PETAJA Latvia State Forest Research Institute "Silava”, Rigas street 111, LV-2169, Salaspils, Latvia; guna.petaja@silava.lv

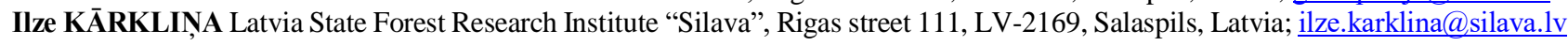

Latvia's forest reference level (FRL) should take in account the future impact of dynamic age-related forest characteristics in order to avoid unduly constraining the forest management intensity as a core element of sustainable forest management practice, with the aim of maintaining or strengthening long-term carbon sinks. The basic for calculations of GHG (greenhouse gas) projections is AGM (Forest growth model) and EPIM (Emissions Projections and Inventory Model). The scope of the study is to verify applicability of the AGM model in elaboration of the forestry projections for elaboration of the FRL according to regulation (EU) 2018/841.
\end{abstract}

Keywords: forest reference level, modelling, $A G M$

\section{INTRODUCTION}

The net GHG emissions in Latvia in 2017 was 9.6 mill. tons $\mathrm{CO}_{2}$ eq. including Land Use, Land Use Change and Forestry (LULUCF) sector and 11.3 mill. tons $\mathrm{CO}_{2}$ eq. without Land Use, Land Use Change and Forestry (LULUCF) sector (Ministry of Environment protection and Regional Development). Latvia recently joined to the initiative of the European Commission "A clean planet for all a European strategic long-term vision for a prosperous, modern, competitive and climate neutral economy" (COM(2018) 773 ) by setting the neutrality target in 2050. According to this strategic target the GHG emissions in Latvia has to be reduced by nearly 10 mill. tons $\mathrm{CO}_{2}$ eq. during the following 30 years. The LULUCF sector will have important role in reaching this target because of considerably potential to decrease GHG emissions and to contribute to the national target by the increase of deliveries of sustainably produced biomass, ensuring replacement effect in energy sector and material production, and by implementation of the climate change mitigation measures in forest land, cropland, grassland and wetlands.

According to LULUCF Regulation (EU) 2018/841 removals from managed forest land should be accounted against a forward-looking Forest Reference Level (FRL) including harvested wood products (HWP). The projected future removals by sinks should be based on an extrapolation of forest management practices and intensity from a reference period. A decrease in a sink relative to the reference level should be accounted for as debits (The European Parliament and the Council of the European Union).

This LSFRI Silava forest research long-term prognosis model (AGM) is developed as a simulation model. The structure and calculation principles are described in details in the report on the development of AGM model (Donis, Šñepsts, 2014; Donis et.al., 2016a; Donis et.al., 2016b; Donis et.al., 2017; Donis et.al., 2018).

In forest research modelling data from the National Forest inventory (NFI) database was used, but it is possible to use data from the State Forest Service (SFS) registry by changing the format according to the NFI data.

Changes to the forest stand in the programme are modelled on a forest element level where a collection of individuals of the same species, generation and level are considered a forest element. Changes in forest resources are modelled in five year periods.

The process of existing tree stand modelling is deterministic, but renewing and harvesting are stochastic processes. In modelling the growing process of tree stands growing process models developed by LVMI Silava were used (Donis, Šñepsts, 2014; Donis et.al., 2016a; Donis et.al., 2016b; Donis et.al., 2017; Donis et.al., 2018).

The default forest resource long term prognosis model works according to current (last five years) management practice, but users will be able to set a variety of management scenarios.

Changes in forest resources are modelled according to current forest management practice in the default setting, but it is possible to set a variety of management scenarios.

The process of forest resource prognosis consists of three stages:

Copyright ( 12019 The Authors. Published by Vytautas Magnus University. This is an open-access article distributed under the terms of the Creative Commons Attribution License (CC BY 4.0), which permits unrestricted use, distribution, and reproduction in any medium, provided the original author and source are credited. 
1. creating a data table suitable for modelling;

2. defining a management scenario and criteria of suitable sectors;

3. modelling changes in forest resources for $\mathrm{n}$ periods in the future.

The scope of the study is to verify applicability of the AGM model in elaboration of the forestry projections necessary for elaboration of the FRL according to regulation (EU) 2018/841, respectively to reconstruct time series characterizing reference level.

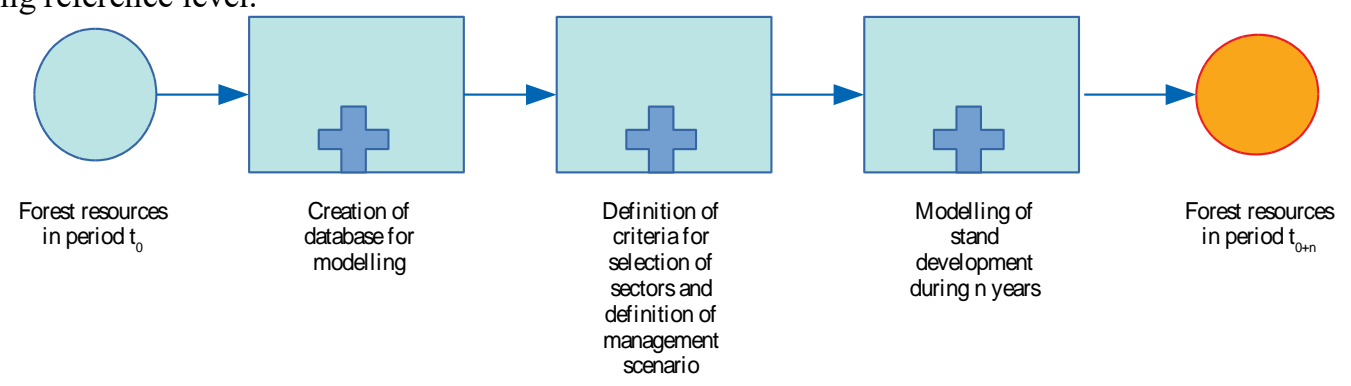

Figure 1. Scheme of the LSFRI Silava changes in forest resources projections process based on NFI data.

\section{METHODS}

Verification of the AGM model was done in 225 plots measured in the $3^{\text {rd }}$ NFI cycle. The parameters for selection of the plots are:

- the dominating tree species is pine, spruce or birch;

- $\quad$ sampling plots are not divided into sectors;

- there has been no felling between stock-taking.

Sampling plots used in data analysis represent a wide range of age, height and density (Table 1 in [9]). Equations approximated by LVMI Silava were used for calculation of changes in the inventory data (Donis, Şnepsts, 2014; Donis et.al., 2016a; Donis et.al., 2016b; Donis et.al., 2017; Donis et.al., 2018). All parameters were calculated separately for the forests elements with average tree height less than $1.3 \mathrm{~m}$ and other forest elements. Equations are expressed as LibreOffice Calc (compatible with Microsoft Excel) formulas to simplify verification of calculations in spreadsheet based models.

Height of the forest elements with average tree height less than $1.3 \mathrm{~m}$ is modelled for each species according to the site quality of the forest site type. The site index of the previous rotation is used in modelling if such information is available. Average height of the forest element at the end of the calculation period is estimated using following formula:

$$
\left.\mathrm{h}_{2}=\mathrm{h}_{1}+\left(\alpha_{1}+\left(\alpha_{2} * \mathrm{~B}^{\wedge} \alpha_{3}\right) /\left(\alpha_{4} \wedge \alpha_{3}+\mathrm{B}^{\wedge} \alpha_{3}\right)\right)^{*} \Delta \mathrm{t} /(\Delta \mathrm{a}+5)\right) \text {, where }
$$

$\mathrm{h}_{2}$ - average height of forest element at the end of the update period, $\mathrm{m}$;

$\mathrm{h}_{1}$ - average height of forest element at the beginning of the update period, $\mathrm{m}$;

$\mathrm{B}$ - site quality of forest element (0-6);

$\Delta \mathrm{t}$ - duration of update period, years;

$\Delta \mathrm{a}$ - difference between biological and breast height age of forest element, years;

$\alpha_{1-3}-$ coefficients, Table 2 in (Šnepsts at. El., 2018).

If the height of a forest element is above $1.3 \mathrm{~m}$, average height of the forest element at the end of the calculation period is estimated using following formula:

$\mathrm{h}_{2}=1.3+\mathrm{a}_{2} \wedge \alpha_{1} /\left(\alpha_{2}+\alpha_{3} * 100 *\left(\left(\mathrm{a}_{1} \wedge \alpha_{1} /\left(\mathrm{h}_{1}-1.3\right)-\alpha_{2}\right) /\left(\alpha_{3} * 100+\mathrm{a}_{1} \wedge \alpha_{1}\right)\right)+\left(\left(\mathrm{a}_{1} \wedge \alpha_{1} /\left(\mathrm{h}_{1}-1.3\right)-\alpha_{2}\right) /\left(\alpha_{3} * 100+\mathrm{a}_{1} \wedge \alpha_{1}\right)\right) * \mathrm{a}_{2} \wedge \alpha_{1}\right)$,

where

$\mathrm{h}_{2}$ - average height of forest element at the end of update period, $\mathrm{m}$;

$\mathrm{h}_{1}$ - average height of forest element at the beginning of update period, $\mathrm{m}$;

$\mathrm{a}_{1}$ - age of forest element at the height of $1.3 \mathrm{~m}$ at the beginning of the update period, years

$\mathrm{a}_{2}-$ age of forest element at the height of $1.3 \mathrm{~m}$ at the end of the update period, years

$\alpha_{1-3}-$ coefficients, Table 3 in [9].

The height of a forest element is updating until it reaches the respective maximum height (Table 3 in (Šnepsts at. el., 2018). The height of the forest element remains intact if it is bigger than the maximum height according to Table 3 in (Šñepsts at. El., 2018).

Diameter at breast height of the forest elements with average tree height less than $1.3 \mathrm{~m}$ is modelled as a secondary parameter using average height and taking the $\mathrm{H} / \mathrm{D}$ ratio to be 1.2. Average diameter at breast height of the forest element at the end of the calculation period is estimated using following formula:

$$
\mathrm{d}=\mathrm{h} / 1.2
$$

Where

$\mathrm{d}$ - average diameter at breast height of forest element, $\mathrm{cm}$; 
$\mathrm{h}$ - average height of forest element, $\mathrm{m}$.

If the height of the forest element is above $1.3 \mathrm{~m}$, the average diameter at breast height is modelled from the initial average diameter, age and relative density of the $1^{\text {st }}$ floor using following formula:

$$
\begin{gathered}
\mathrm{d}_{2}=1.3+\mathrm{a}_{2} \wedge \alpha_{1} /\left(\alpha_{0} * \mathrm{RB}+\alpha_{3} * 100 *\left(\left(\mathrm{a}_{1} \wedge \alpha_{1} /\left(\mathrm{d}_{1}-1.3\right)-\alpha_{2} * \mathrm{RB}\right) /\left(\alpha_{3} * 100+\mathrm{a}_{1} \wedge \alpha_{1}\right)\right)+\left(\left(\mathrm{a}_{1} \wedge \alpha_{1} /\left(\mathrm{d}_{1}-1.3\right)-\right.\right.\right. \\
\left.\left.\left.\alpha_{2} * \mathrm{RB}\right) /\left(\alpha_{3} * 100+\mathrm{a}_{1} \wedge \alpha_{1}\right)\right) * \mathrm{a}_{2} \wedge \alpha_{1}\right),
\end{gathered}
$$

where

$\mathrm{d}_{2}$ - average diameter at breast height of forest element at the end of update period, $\mathrm{cm}$;

$\mathrm{d}_{1}-$ average diameter at breast height of forest element at the beginning of update period, $\mathrm{cm}$;

$\mathrm{a}_{1}$ - age at $1.3 \mathrm{~m}$ height of forest element at the beginning of update period, years;

$\mathrm{a}_{2}-$ age at $1.3 \mathrm{~m}$ height of forest element at the end of update period, years;

$\mathrm{RB}$ - relative density of the I floor of the forest stand;

$\alpha_{1-3}-$ coefficients, Table 4 in [9].

Number of trees of the forest elements with average tree height less than $1.3 \mathrm{~m}$ at the end of calculation period is estimated assuming natural mortality of $1 \%$ using following formula:

$$
\mathrm{n}_{2}=(1-0.01 * \mathrm{t}) * \mathrm{n}_{1}
$$

where

$\mathrm{n}_{2}$ - number of trees in forest element at the end of update period, $\mathrm{ha}^{-1}$;

$\mathrm{n}_{1}$ - number of trees in forest element at the beginning of update period, $\mathrm{ha}^{-1}$.

If the height of forest element is above $1.3 \mathrm{~m}$, the number of trees is calculated as a secondary parameter from projected forest element basal area and diameter using following formula:

$$
\mathrm{n}=40000 * \mathrm{~g} / \mathrm{pi}() / \mathrm{d}^{\wedge} 2
$$

where

$\mathrm{n}$ - number of trees in forest element, ha ${ }^{-1}$;

$\mathrm{g}$ - basal area of forest element, $\mathrm{m}^{2} \mathrm{ha}^{-1}$;

$\mathrm{d}$ - average diameter at breast height of forest element, $\mathrm{cm}$.

Basal area of the forest elements with average tree height less than $1.3 \mathrm{~m}$ is $0 \mathrm{~m}^{2} \mathrm{ha}^{-1}$, but after reaching a height of $1.3 \mathrm{~m}$ the basal area is determined using projected number of trees and diameter with following formula:

$$
\mathrm{g}=\operatorname{pi}() * \mathrm{~d}^{\wedge} 2 * \mathrm{n} / 40000
$$

Where

$\mathrm{g}$ - basal area of forest element, $\mathrm{m}^{2} \mathrm{ha}^{-1}$;

$\mathrm{d}$ - Diameter of forest element at breast height, $\mathrm{cm}$;

$\mathrm{n}$ - Number of trees in forest element, $\mathrm{ha}^{-1}$.

If the height of forest element is above $1.3 \mathrm{~m}$ changes in the basal area of the forest element depend on the projected basal area difference and maximum basal area.

The calculation the basal area difference depends on the length of the projection period, basal area and age of the forest element. If the basal area of the forest element is less than $10 \mathrm{~m}^{2} \mathrm{ha}^{-1}$ or the age at breast height more than the basal update border age $\left(\mathrm{A}_{\text {lim }}\right)$ given in Table 5 in (Šnepsts at. el., 2018), or the update period is longer than 20 years, formula No. 9 is used, in other cases formula No. 8 is used.

$$
\begin{gathered}
\mathrm{g}_{2}{ }_{2}=\mathrm{g}_{1}+\left(\alpha_{0}+\alpha_{1} * \mathrm{a}_{1} / 100+\alpha_{2} /\left(\mathrm{a}_{1} / 10\right)^{\wedge} 2+\alpha_{3} * \mathrm{~g}_{1} / \mathrm{a}_{1}+\alpha_{4} * \mathrm{GL} / \mathrm{a}_{1}+\alpha_{5} * \mathrm{SI} / \mathrm{a}_{1}\right) *\left(\mathrm{a}_{2}-\mathrm{a}_{1}\right) \\
\mathrm{g}_{2}{ }_{2}=\mathrm{g}_{1}+\mathrm{g}_{1} *\left(\alpha_{0}+\alpha_{1} * \mathrm{a}_{1} / 100+\alpha_{2} / \mathrm{a}_{1} \wedge 2\right) *\left(\mathrm{a}_{2}-\mathrm{a}_{1}\right),
\end{gathered}
$$

Where

$\mathrm{g}_{2}^{\prime}-$ projected basal area of forest element at the end of period, $\mathrm{m}^{2} \mathrm{ha}^{-1}$;

$\mathrm{g}_{1}$ - basal area of forest element at the beginning of update period, $\mathrm{m}^{2} \mathrm{ha}^{-1}$;

$\mathrm{a}_{1}$ - age of forest element at $1.3 \mathrm{~m}$ high at the beginning of update period, years;

$\mathrm{a}_{2}$ - age of forest element at $1.3 \mathrm{~m}$ high at the end of update period, years;

GL - sum of basal area for forest element equal or higher than the selected forest element (if forest element of floor I, the basal area of floor I, if floor II forest element, then the sum of basal area of floor I and II, if floor II forest element, then the total basal area of the tree stand), $\mathrm{m}^{2} \mathrm{ha}^{-1}$;

SI - projected height of forest element at a specific age at breast height (Table 5 in (Šnepsts at. el., 2018), AsI), m; $\alpha_{\mathrm{i}} ; \beta_{\mathrm{i}}-$ coefficients from Table 5 and 6 in (Šñepsts at. el., 2018). 
Formula No. 10 and 11 are used to project the potential basal area of the forest element, however it may not exceed the theoretically possible basal area.

$$
\begin{gathered}
g_{\max }=\alpha_{1} /\left(1+\left(d / \alpha_{2}\right)^{\wedge} \alpha_{3}\right) * i p \\
g_{\max }=\beta_{1} *\left(1-\exp \left(-\beta_{2} * h\right)\right) * i p
\end{gathered}
$$

where

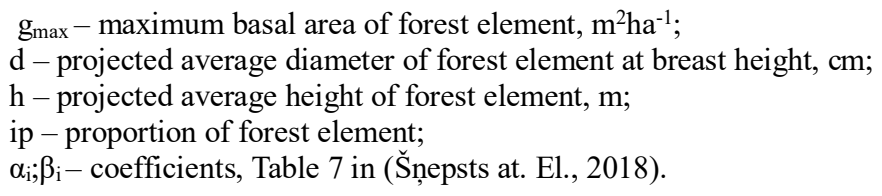

Formula 10 is used to calculate the maximum basal area of a forest stand in which thinning has been done in the last 18-22 years, if there has been no thinning for a prolonged period of time, the maximum basal area is calculated using formula 11 .

The basal area of individual forest elements is projected as the minimum basal area from the potential basal area of the forest element and from the calculated maximum basal area of the forest element using following formula:

$$
\mathrm{g}_{2}=\min \left(\mathrm{g}_{2}{ }_{2} ; \mathrm{g}_{\max }\right)
$$

where

$\mathrm{g}_{2}-$ basal of the forest element at the end of the update period, $\mathrm{m}^{2} \mathrm{ha}^{-1}$;

$\mathrm{g}_{2}$ - projected basal area of the forest element at the end of the update period (formula 8 or 9), $\mathrm{m}^{2} \mathrm{ha}^{-1}$;

$\mathrm{g}_{\max }-$ maximum basal area pf the forest element (formula 10 or 11 ), $\mathrm{m}^{2} \mathrm{ha}^{-1}$.

Growing stock of the forest stand is assumed to be $2 \mathrm{~m}^{3} \mathrm{ha}^{-1}$ before reaching a height of $2 \mathrm{~m}$ (height of the dominating tree species in the $1^{\text {st }}$ floor), but the wood stock of individual forest elements is calculated from their proportion using following formula:

$$
\mathrm{m}=2 * \mathrm{ip}
$$

where

$\mathrm{m}$ - wood stock of the forest element $\mathrm{m}^{3} \mathrm{ha}^{-1}$;

ip - proportion of the forest element.

After reaching a height of $2 \mathrm{~m}$ the growing stock is calculated using the I. Liepa formula for individual tree volume (Liepa, 1996) using number of trees, average tree height and square average diameter:

$$
\mathrm{m}=\psi^{*} \mathrm{~h}^{\wedge} \alpha^{*} \mathrm{~d}^{\wedge}\left(\beta^{*} \log 10(\mathrm{~h})+\varphi\right)^{*} \mathrm{n}
$$

where

$\mathrm{m}$ - Wood stock of the forest element, $\mathrm{m}^{3} \mathrm{ha}^{-1}$;

$\mathrm{h}$ - Average height of forest element, $\mathrm{m}$;

$\mathrm{d}$ - Average diameter of forest element at breast height, $\mathrm{cm}$;

$\mathrm{n}-$ Number of trees in forest element, $\mathrm{ha}^{-1}$;

$\psi ; \alpha ; \beta ; \varphi-$ Coefficients.

The following statistical indicators are used to describe changes in projected growing stock [11]:

Mean deviation

$$
\text { MRES }=\frac{\sum\left(y_{i}-\hat{y}_{l}\right)}{n}
$$

Mean absolute deviation

$$
\text { AMRES }=\frac{\sum\left|y_{i}-\hat{y}_{l}\right|}{n}
$$

Coefficient of variation

$$
R M S E_{\%}=\frac{\sqrt{\frac{\sum\left(y_{i}-y_{l}\right)^{2}}{n-1-p}}}{\dot{y}_{l}} 100,
$$

where

$y_{i}$ - Measured value;

$\hat{y}_{l}$ - Calculated value;

$\dot{y}_{l}$ - Arithmetic average measured value;

$\hat{y}_{l}$-Arithmetic average calculated value;
Mean relative deviation

$$
\operatorname{MRES}_{\%}=\frac{\frac{\sum\left(y_{i}-\hat{y}_{l}\right)}{n}}{y_{l}^{\prime}} 100
$$

Standard deviation

$$
R M S E=\sqrt{\frac{\sum\left(y_{i}-\hat{y}_{l}\right)^{2}}{n-1-p}}
$$


$\mathrm{p}$ - Number of parameters in equation;

$\mathrm{n}$ - Number of observations.

At the end calculated data were compared with the NFI measurement results to identify if the difference of the forest inventory data (diameter, tree height, basal area and growing stock) is significant.

\section{RESULTS OF RESEARCH}

Measured and projected total and wood stock in floor I of the tree stand are compared to describe the precision of the projection system. Statistical evaluation of other inventory indicators (height, diameter at breast height, basal area) is done during equation development (Donis, Šṇepsts, 2014; Donis et.al., 2016a; Donis et.al., 2016b; Donis et.al., 2017; Donis et.al., 2018). Wood stock difference depending on dominating tree species is not analysed separately as in the sampling plots there are forest elements of species other than the dominating one.

Arithmetic average deviation in the $1^{\text {st }}$ floor of the tree stand (the difference between measured and projected values) is $7 \mathrm{~m}^{3} \mathrm{ha}^{-1}$, but the total growing stock deviance is $1 \mathrm{~m}^{3} \mathbf{h a}^{-1}($

Table 1). In both cases the deviance does not exceed 5\%. The variation coefficient of projected wood stock in the $1^{\text {st }}$ floor of the tree stand is $13 \%$, but for total wood stock $-12 \%$, so the variation in dispersion of the projected wood stock can be considered to be sufficiently stable.

Table 1: Statistical indicators of the projected wood stock

\begin{tabular}{|c|c|c|c|c|c|c|c|c|c|}
\hline Indicator & $\begin{array}{l}\text { Dominating } \\
\text { tree species }\end{array}$ & Ave. & MRES & MRES \% & AMRES & RMSE & RMSE \% & $\mathbf{R}$ & $\mathbf{N}$ \\
\hline \multirow{4}{*}{$\begin{array}{l}\text { Wood stock in } \\
1^{\text {st }} \text { floor }\end{array}$} & Pine & 264 & 10 & 4 & 23 & 32 & 12 & 0.981 & 140 \\
\hline & Spruce & 339 & 13 & 4 & 30 & 44 & 13 & 0.963 & 51 \\
\hline & Birch & 244 & -2 & -1 & 27 & 40 & 17 & 0.933 & 64 \\
\hline & All & 274 & 7 & 3 & 25 & 35 & 13 & 0.971 & 255 \\
\hline \multirow{4}{*}{$\begin{array}{l}\text { Total wood } \\
\text { stock }\end{array}$} & Pine & 288 & 6 & 2 & 23 & 32 & 11 & 0.984 & 140 \\
\hline & Spruce & 362 & 1 & 0 & 32 & 45 & 12 & 0.957 & 51 \\
\hline & Birch & 290 & -11 & -4 & 31 & 43 & 15 & 0.957 & 64 \\
\hline & All & 303 & 1 & 0 & 27 & 36 & 12 & 0.975 & 255 \\
\hline
\end{tabular}

According to the Shapiro test the distribution of the deviance (difference between measured and projected wood stock) of the total wood stock is a normal distribution $(\mathrm{p}=0.0058)$, but the distribution of deviance of the wood stock in floor I of the tree stand is not a normal distribution. (0.0029; Figure 2).
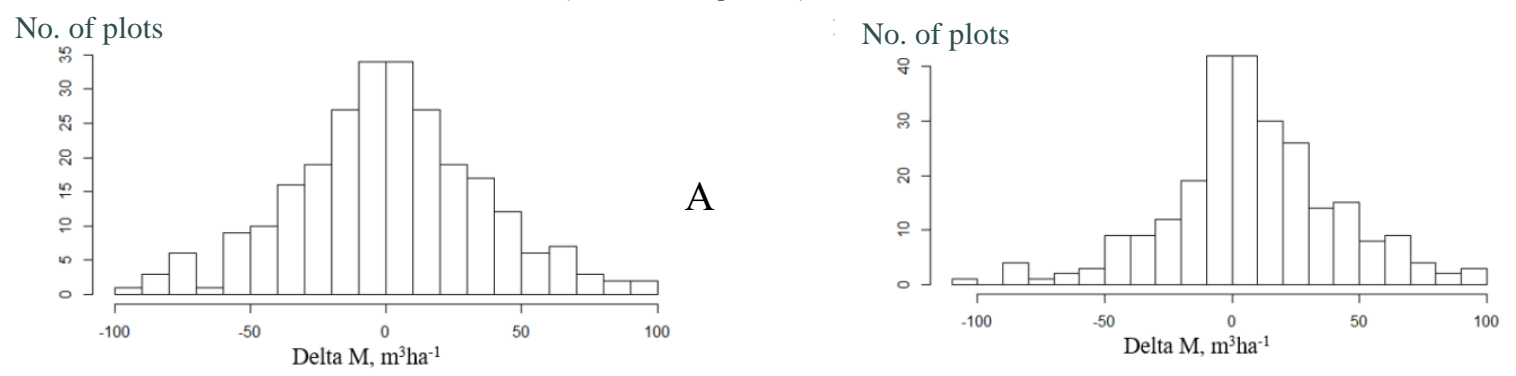

Figure 2. Number of sampling plots sorted by difference between measured and projected wood stock (Delta M), where A - total wood stock in stand, B - wood stock in $1^{\text {st }}$ floor of the stand

Since the wood stock deviance in the $1^{\text {st }}$ floor of the tree stand is not distributed in a normal distribution and selection of sampling plots is random without checking if the selected sampling plots objectively describe the situation in Latvia, the Wilcoxon test was used to compare projected and measured wood stock. During the test it was observed that there is not a notable difference between the projected and measured total wood stock $(\mathrm{p}=0.7888)$, but the wood stock in floor I of the tree stand is consistently projected with lower values $(\mathrm{p}=0.0001)$.

The deviance of the projected wood stock (total and $2^{\text {nd }}$ floor) is observed to have a weak linear correlation with initial age and site quality of the tree stand (Figure 3). Due to the large number of observations this statistical correlation is important, however they look more like a chaotic collection of values (Figure 3). Therefore projected wood stock can be considered independent from the age and productivity of the stand. 

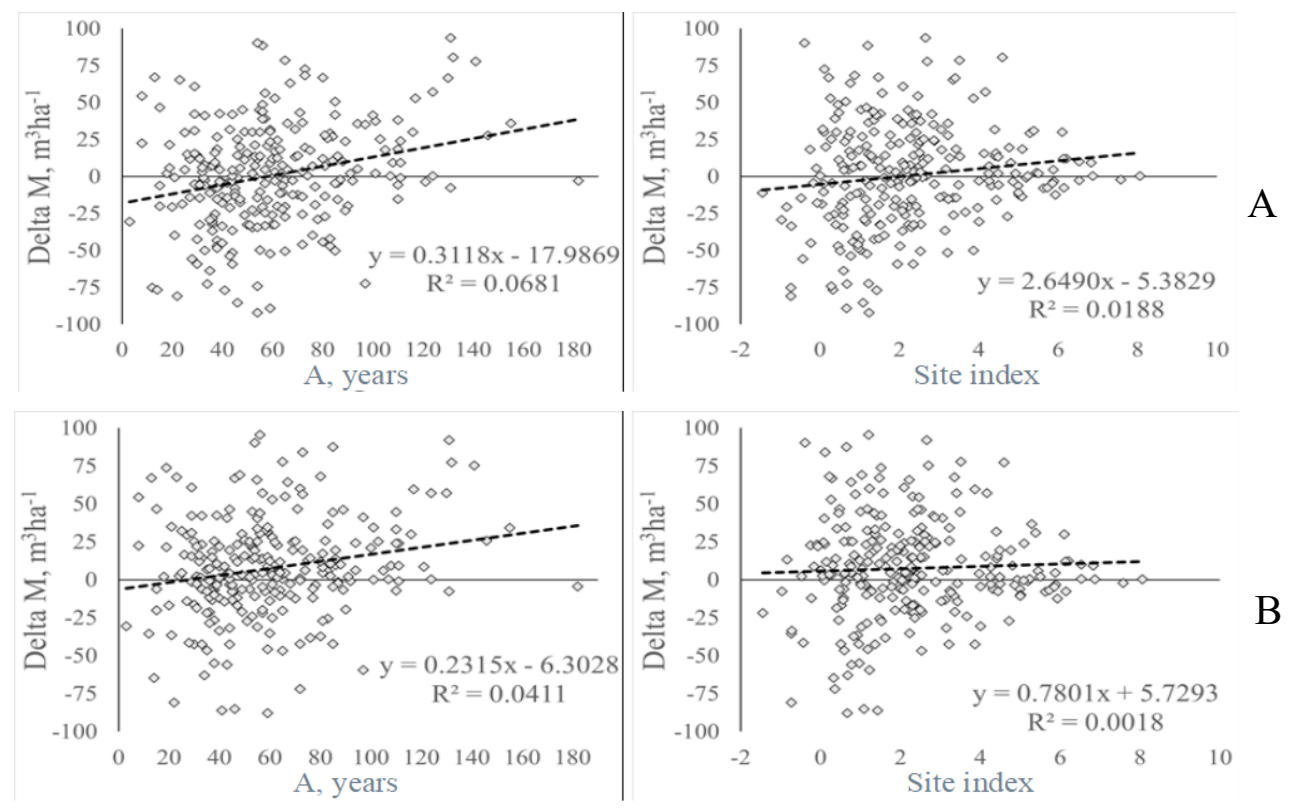

Figure 3. Difference between measured and projected wood stock (Delta $M$ ) and initial age (A) and site quality of the stand, where A - total wood stock in stand, B - wood stock in floor I of the stand.

\section{CONCLUSIONS}

1. The selected set of NFI plots characterizes spruce, pine and birch forests not affected by disturbances, verification of the model using all NFI plots would lead to inconsistency because of wind blow in 2005, which significantly affected forest age structure, harvest intensities and growth rates due decrease of resilience of forest stands.

2. Results of the verification proves that modelled results sufficiently represents difference in the total growing stock; however, difference in the $1^{\text {st }}$ floor sufficiently differs in modelled and measured data; in other words, this modelling exercise proves that the model can be used in projections of forest growth.

3. Age structure should not be used as a parameter in modelling, except for regenerative felling, which is not considered in the exercise, because forest stand characteristics are significantly affected by site productivity and management history.

\section{REFERENCES}

1. The European Parliament and the Council of the European Union. Regulation (EU) 2018/841 of the European Parliament and of the Council of 30 May 2018 on the inclusion of greenhouse gas emissions and removals from land use, land use change and forestry in the 2030 climate and energy framework, and amending Regulation (EU) No 525/2013 and Decision No 529/2013/EU (Text with EEA relevance) PE/68/2017/REV/1. https://eur-lex.europa.eu/eli/reg/2018/841/oj (2018, accessed 27 October 2018).

2. Ministry of Environment protection and Regional Development. Latvia's National Inventory Report Submission under UNFCCC and the Kyoto protocol Common Reporting Formats (CRF) 1990 - 2017. Riga: Ministry of Environmental Protection and Regional Development of the Republic of Latvia.

3. $\operatorname{COM}(2018) 773$ final Communication from the Commission to the European Parliament, the European Council, the Council, the European Economic and Social Committee, the Committee of the Regions and the European Investment Bank A clean planet for all a European strategic long-term vision for a prosperous, modern, competitive and climate neutral economy. https://ec.europa.eu/clima/sites/clima/files/docs/pages/com 2018733 en.pdf (2018, accessed 24 June 2019).

4. Donis J., Šñepsts G.. Zinātniskā pamatojuma izstrāde informācijas aktualizācijai meža valsts reǵistrāa (Elaboration of scientific substantiation for updating of information in the state forest inventory). Salaspils: LVMI Silava (2014, accessed 27 October 2018). (In Latvian)

5. Donis J., Šṇepsts G., Šēnhofs R., Treimane A., Zdors L. Augšanas gaitas modeḷu pilnveidošana, 1. etapa starpatskaite (Improvement of growth models, ${ }^{\text {st }}$ periodic report). Salaspils: LVMI Silava (2016a, accessed 27 October 2018). (In Latvian)

6. Donis J., Šṇepsts G., Šēnhofs R., Treimane A., Zdors L. Augšanas gaitas modelu pilnveidošana, 2. etapa starpatskaite (Improvement of growth models, $2^{\text {nd }}$ periodic report). Salaspils: LVMI Silava (2016b, accessed 27 October 2018). (In Latvian)

7. Donis J., Šñepsts G., Zdors L. Augšanas gaitas modelu pilnveidošana, 3. etapa starpatskaite (Improvement of growth models, $3^{\text {nd }}$ periodic report). Salaspils: LVMI Silava (2017, accessed 27 October 2018). (In Latvian)

8. Donis J., Šṇepsts G., Šēnhofs R., Zariņ̌ J., Zdors L. Augšanas gaitas modeḷu pilnveidošana, pārskats par pētījuma 2018. gada rezultätiem (Improvement of growth models, report on research results in 2018). Salaspils: LVMI Silava (2018, accessed 27 October 2018). (In Latvian)

9. Šñepsts G, Bārdule A, Lazdina D. Verification of AGM model (report). 2018-05-1; Salaspils: LSFRI Silava (2018, accessed 20 October 2018).

10. Liepa I.. Pieauguma mācība (Growth theory). Jelgava: LLU; 1996.

11. Von Gadow K., Hui G.. Modelling Forest Development. Dordrecht: Springer Netherlands. Epub ahead of print 1999. https://doi.org/10.1007/978-94-011-4816-0 